\title{
European Journal of
}

\section{Philosophy, Culture and Religious Studies}

\section{(EJPCR)}

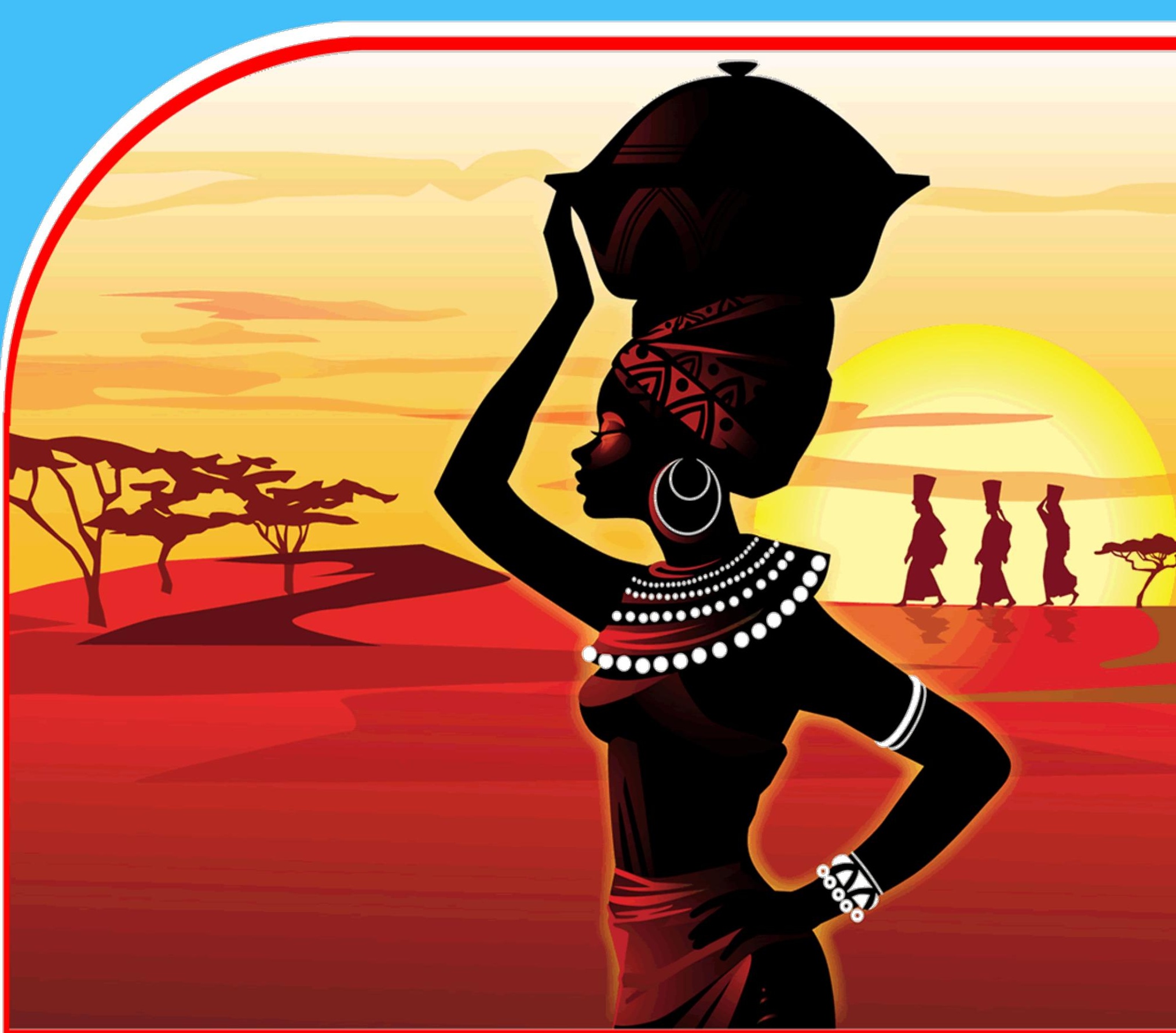

FAITH BASED OGANIZATIONS AND THE THEOLOGY OF POVERTY AND DEATH IN VIHIGA COUNTY, KENYA AJP $\widehat{e}$ Dr. Hezekiah Obwoge, Prof. O.M.J. Nandi 


\title{
FAITH BASED OGANIZATIONS AND THE THEOLOGY OF POVERTY AND DEATH IN VIHIGA COUNTY, KENYA
}

\author{
${ }^{1 *}$ Dr. Hezekiah Obwoge \\ Lecturer, Jaramogi Oginga Odinga University of Science and Technology \\ *Corresponding Author’s E-mail: obwogezek@gmail.com \\ ${ }^{2}$ Prof. O.M.J. Nandi \\ Professor, Masinde Muliro University of Science and Technology
}

\begin{abstract}
Purpose: The purpose of the study was to assess the role of the Faith Based Organizations in alleviating poverty in Western Kenya.

Methodology: This study is a cross-sectional research that sought to give an examining and descriptive scrutiny of the death beliefs surrounding FBO's activities in Emuhaya District. This study targeted Emuhaya District which has a population of 180,000 people who are members of the FBO's. To obtain data for analysis, qualitative methods of data collection, which include in-depth oral interviews, focus group discussion, observation and documentary analysis, were employed. Questionnaires were prepared and administered according to the information required from the specific groups of respondents. This study utilized secondary sources, which were derived from published books, minutes of developmental meetings in the FBO, reports of the development projects of the church, articles and records from Kenya National Archives. Data collected through the questionnaires and personal interviews, was synthesized systematically and logically compiled to determine the role of FBO in alleviating poverty in Emuhaya District. Data was coded manually and organized under different themes. The researcher then investigated the concepts of liberation and reconstruction in improving the well-being of the poor through an analysis and interpretation of the theological methods of induction (TMI).
\end{abstract}

Results: Based on the findings the study concluded that the CoG-K's teachings are largely pertinent in the development of FBO members and their participation in activities that are designed along people's development needs. Also, the CoG-K has a role to play through her programs like Sisi kwa Sisi and Child Development Centres.

Unique contribution to theory, practice and policy: This research recommends that if Emuhaya District is to develop, it has to place the FBO teachings and theology of option for the poor at the top of the agenda and to consider it as is so often the case, as adjunct to the real core of the work that is, development. The study proposes that for the FBO to improve her input in social concerns of the people, it should reshape its theology of development so that it can fully address the plight of the poor.

Keywords: Faith Based Organizations, poverty alleviation, Western Kenya 


\subsection{INTRODUCTION}

\subsection{Background of the Study}

The present economic situation of Africa in general and Kenya in particular appears to be characterized by poverty and suffering which form relatively high levels of material deprivation. Poverty is a state of human deprivation with regard to personal income, clothing, housing, health care, education, sanitary facilities and human rights (World Bank, 2001). Poverty or being poor in the church's understanding commonly means a state of or lack of what ought to be (Myers, 2000). In both the Bible's Old and New Testament, the poor are the oppressed by both socio-cultural and economic conditions. They are the deprived and the needy beggars. Thus, the theological basis for the option for the poor in the church is that the poor possess a sacramental function in the society (Ibid.).

In Kenya, the 2007 Human Development (HD) Survey showed that the people living in abject poverty constituted $56.3 \%$ of the Kenyan population, and that the situation was deteriorating further as it has continued to rise from 30\% in early 1990's to 56\% by 2007 (MDG Centre, 2009). Over 65\% of the people living in Vihiga County where FBOs are the most dominant denomination, live below the poverty line and are food poor (ESDP, 2008). This means that more than a half of the population in Vihiga County is in some state of poverty. Whereas poverty, religion and corruption may account for some of this plight, many of the poor are victims of natural disasters, famine or drought. Farmers on the other hand, often cannot make an adequate living from their small and infertile land. In addition to suffering, sheer lack of income, the poor are often uneducated and afflicted with physical sickness (Ibid.).

Furthermore, the Kenyan situation could rightly be cited as the best example of glaring disparity between the economically empowered on one side and the marginalized masses on the other. The wealthy have access and control of the market, whereas the poor remain at the mercy of the market dictates even where their own produce is concerned. A report by the Society for International Development (2004) revealed that only a tenth of the 30 million Kenyan controlled the nation's resources and income and that 42 percent of the total wealth of the country is concentrated in the hands of the 10 percent of the population (Galgalo, 2005). This implies that a tenth of the population is gobbling nearly half of the available resources.

Until recently, it was believed that rising poverty could be tackled by increased economic growth that would lead to higher incomes. Growth was seen as a natural process which could be nourished through the application of correct and timely input. Likewise, it could be impeded through bad conditions, but once these constraints were removed the process would continue (Verhelst, 1990:56). Development was seen essentially as a question of increasing gross levels of savings and investment both internally and externally, private and state - until the economy reached a take-off point into self-sustaining development.

The emerging crisis has prompted the continuing search for appropriate approach to, and strategies for solving the problem. Poverty alleviation has been the subject of subsequent National Development Plans, Session Papers, Presidential Commissions, Task Forces, and studies in Kenya. The large range of contributions reflects the pressure on the Government to find solutions to the persistence of poverty in Kenyan society. However the government of 
European Journal of Philosophy, Culture and Religious Studies

ISSN 2520-4696(Online)

Vol.1, Issue 1 No.1, pp1-15, 2017

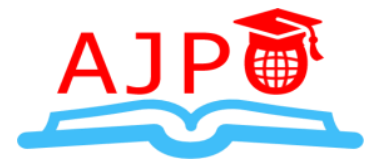

www.ajpojournals.org

Kenya on its part has not sufficiently addressed these needs due to increasing national population growth and the concurrent costs (EDSP, 2008). This inadequacy has been greatly felt in Emuhaya District because of its high density as compared to other rural areas in Kenya (Ibid.). It is in this process of taking initiative in development that existing churches in Emuhaya District have played role in development.

Presently in Vihiga County are a wide range of FBos which are known to actively take part in human development through its agencies such as Compassion International, Youth Empowerment Programs and World Vision. These churches include the Anglican Church of Kenya, Church of God in Kenya, Pentecostal Assemblies of God, Coptic Church, Israeli Nineveh Church, African Interior Church, Salvation Army, Revival Church (CoG-K, 2007), just to mention a few. While acknowledging the role played by these churches in both spiritual and social-economic development, the present work delves its attention to the role played by the FBOs in poverty alleviation to the populace in Vihiga County. The Vihiga County has a population of about 250,000 inhabitants according to the 2009 population's projections (EDP, 2010). Currently, the birth rate is estimated at 3.5\% per annum (Ibid.). Nevertheless, poverty is a complex phenomenon that cannot be eradicated solely by politics, economic policies and financial investments. It is a social construct that cannot be limited to mere economic growth. In order to be authentic, it must be integral; that is, it has to promote the good of each individual and the whole person. Material and spiritual values must be brought together (Pope Paul VI, 1967).

Poverty is a major concern of the FBOs, and countless poverty alleviation programs and campaigns have been developed over time, across the regions. Poverty is defined as having numerous manifestations and characteristics that include low and unreliable income, poor health, and low levels of education, insecurity, disempowerment and isolation from the mainstream of the economic development (Cavanaugh, 2008). These characteristics are also referred to as indicators of measuring poverty (Ibid.). The biblical word on the relation of the community of faith to poverty is clear and unambiguous because God identifies himself with the poor, so too the community of faith is called to special concern for these persons.

Evidently, the important place of spirituality in human development has been acknowledged (Gumo-Kurgat, 2004; Bryant, 1999; Nyaundi, 2003; Vinay, 2005). Secular groups involved in development are beginning to take seriously the religions of communities with whom they work. Scholars are seeking for ethics and morality in development strategies. Therefore, true development be it Christian or non-Christian, requires addressing the spiritual, because it is not possible to alleviate poverty without the spiritual facet. It is in this regard that the church and Christian organizations have made concerted attempts towards answering the cries of the poor in the society. This contribution of the church in alleviating poverty is likely to be enhanced by the fact that Christianity in Africa is growing greatly. This study aims at assessing the role of the FBOs in alleviating poverty in Western Kenya.

\subsection{Problem Statement}

Poverty and beliefs surrounding death is a widespread phenomenon that is of interest to all stakeholders of the development processes including the Faith Based Organizations (FBOs). Documents of earlier studies have focused on the economic systems while underestimating the power and influence of FBOs in the eradication of poverty; thus, relegating religion to a matter of spiritual significance. Vihiga County experiences very high poverty levels that 
European Journal of Philosophy, Culture and Religious Studies

ISSN 2520-4696(Online)

Vol.1, Issue 1 No.1, pp1-15, 2017

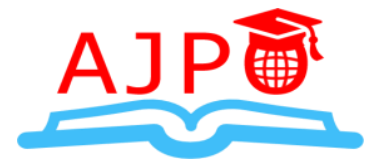

www.ajpojournals.org

stand at $65 \%$ of the total population of Kenya (GoK, 2010; KNBS, 2010; ESDP, 2008). Furthermore, $52.3 \%$ of the households in the County live below poverty levels. Thus, the Vihigas contribution to national poverty is $3 \%$ (Ibid.). However, it is evident that economic systems alone to date have been inadequate and the growth of poverty has not been reversed (Speckman, 2001; Ogot, 1999; Nandy, 1998). People do not live by economics or science and technology alone. Thus, the role of religion in poverty eradication has not been studied yet human spirit and determination are cornerstone for poverty alleviation and wealth creation.

Consequently, this study seeks to examine the role of religion in addressing the phenomenon of poverty. In particular the study seeks to assess the role of FBOs in addressing the problem of poverty in Vihiga County with special reference to Emuhaya District, Western Kenya. At the moment, FBOs have gained a wide acceptance among the people of Emuhaya District of Western Kenya and also influenced their way of life. The study seeks therefore to determine the contributions of the FBOs teachings to people's participation in poverty alleviation and further to examine to what extent the said projects have been successful in achieving their goals in the midst of the challenge of death.

\subsection{Objectives of the Research}

To assess the role of the Faith Based Organizations in alleviating poverty in Western Kenya

\subsection{JUSTIFICATION OF THE STUDY}

The study is justifiable base on the facts that poverty reduction is a national challenge. Experience with the post-independence anti-poverty policies reveals that Kenya has not achieved much progress during the last 40 years (Saitoti, 2002). At the outset, Kenya hoped to eliminate poverty through trade and industrial growth. It was seen as a short-term hardship, which would disappear as the nation developed and grew in monetary terms. Poverty is now recognized as a major threat to every significant section of Kenya. It is also increasingly recognized that economic growth alone will not be sufficient to reduce poverty (Ogot, 1999).

Furthermore, poverty is a problem encompassing boundaries beyond physical aspects thus poverty reduction needs to be supported by a combination of measures. In this regard, there is a growing recognition of the role of the church in poverty alleviation and hence improving the quality of life (Vinay, 2005). Even though secular programs meant to alleviate poverty have ignored or underestimated the importance of the church in alleviating poverty and even sustaining relief and development, church programs and its gospel has continued to be a force for social change (Ibid.). Galgalo, captures the essence of the situation when he says:

The deep economic problems of today do in fact, have spiritual roots and are related to forms of unbelief - for which a solution is present. And to make the answer more apparent we urgently need personal Christian reflection on economic life - in our schools as well as in universities (Galgalo, 2004:23).

In this context, Africa must welcome a serious examination of its record to identify approaches that go beyond economics; religion and culture has been the missing dimension in this experience (Ogot, 1999). Experience has shown that the consequences of development are deeply rooted in the cultural, value and psychological systems. They cannot be simply evicted by economics and political intervention, reduction as they may be (Ibid.). In view of the fact that religion is not lived in a vacuum and that spiritual progress and worldly 
development is necessarily interrelated (Tarino, 2005), the human soul that is truly seeking to save itself is fully social. The progress of religion in this world brings with it an immeasurable improvement in the conditions of human social life. This however raises questions with regard to the communication of the whole of the gospel in relation to the existing social-economic situation.

Consequently, FBOs is subject to this assessment as a way of challenging the approach of excluding the impact of religion to economics and faith concerns. Accordingly, the role of CoG-K in combating poverty is subject and justified for assessment. It is therefore important for any analysis or recommendations to take this into account. This study is aimed, therefore, at filling these shortcomings. The findings will provide strategies for the policy and program development to scholars, theologians and economic planners.

\subsection{RESEARCH METHODOLOGY}

This study is a cross-sectional research that sought to give an examining and descriptive scrutiny of the death beliefs surrounding FBO's activities in Emuhaya District. This study was carried out in Emuhaya District of Vihiga County. The sample respondent in this study was drawn from the population of the CoG-K adherents in Emuhaya District. This study targeted Emuhaya District which has a population of 180,000 people who are members of the FBO's (CoG-K Assembly, 2007). These were represented in all the 141 FBO centers in Emuhaya District. Other participants who were thought to have important information for the research were the FBO leaders, directors and the church elders who were purposively sampled as discussed under sampling procedures. Saturated sampling technique was used to opt for the 4 administrative heads of the FBO namely the Chairman, the General Secretary, Treasurer, trustee and the 16 heads of departments for in-depth interviews. To obtain data for analysis, qualitative methods of data collection, which include in-depth oral interviews, focus group discussion, observation and documentary analysis, were employed. Questionnaires were prepared and administered according to the information required from the specific groups of respondents. It was significant for the researcher to do in-depth oral interviews for the church leaders in order to facilitate exhaustive probing on key question from the formulated questionnaires. This type of interview was chosen because the researcher has a great deal of freedom to probe and ask specific queries during the course of the interview. This study utilized secondary sources, which were derived from published books, minutes of developmental meetings in the FBO, reports of the development projects of the church, articles and records from Kenya National Archives. Pertinent information was also collected from hospital and compassion projects in the community. Other services statistics were obtained from the ministry of Finance and Planning to explain quantitative information about the District.Data collected through the questionnaires and personal interviews, was synthesized systematically and logically compiled to determine the role of FBO in alleviating poverty in Emuhaya District. Data was coded manually and organized under different themes. The researcher then investigated the concepts of liberation and reconstruction in improving the well-being of the poor through an analysis and interpretation of the theological methods of induction (TMI). 


\subsection{RESULTS AND DISCUSSIONS}

\subsection{Death and Funeral}

Death, burial and mourning are an intricate part of the FBO's beliefs and practices. Death is part of the physical separation of a person from the church, community and provides the individual the opportunity to join the ranks of the departed (Smith-Akubue, 1995:152). Procedure followed and the amount of money spent when burying a FBO member showed a number of variations according to the sex, age, and social status as well as certain peculiarities of the deceased. According to Kageni (2008:34):

Kenyans are burying more than Sh 7 billion every year in funeral expenses and burial ceremonies. This year, at a time when the country is trapped in a biting economic crunch fanned by inflation and high fuel prices, more money than that allocated to some key government ministries for development this year will go into graves. The church is the main culprit.

Kenyans have not adjusted funeral costs downwards and invested the money productively for bereaved kin (Anjieho: OI, 13/02/2008). Readiness by the FBO members to splash money on the dead has given rise to a thriving funeral service industry that is visible in every market place in Emuhaya District. For instance, the casket making workshops are numerous at Luanda market. Statistics of death of an FBO members in Emuhaya District released by the church (CoG-K: 2006), and the vast fortune buried annually is a contradiction to terms for poverty-stricken members of the CoG-K. Managers of leading and upcoming funeral homes, on the other hand, celebrate, as FBO members in Emuhaya district indicate no desire to turn back from their ruinous way of forking out money. Yet the church hierarchy has no official policy towards the spending of its members toward funerals (Ibid.)

Observation carried out among the FBO members in Emuhaya District show that all the transactions for funeral services are paid in cash. No funeral home offers services on credit. This means the hefty budgets drawn in respect of funerals have to be raised in an average time of two weeks, between death and burial. Western Kenya stands out in lavish burials and elaborate feasts (Obunde: OI, 11/12/2008). Transporting bodies over long distances also contribute to the higher costs. The 'send-off depends on the status of a person'. The living people believe that the dead watch over them. As Anjere (OI, 11/11/2008) reports:

The funeral of a common person takes place on the day following his death, so that there is one full night for keeping vigil by the dead and permits even those of his relatives who live far to receive the death message and to come and see their dead kinsman before burial. Elders of higher social status are buried on the second or third day after death, and in the case of the clans-head the burial may even be delayed until the fourth day. Such a delay is founded on the belief that it will please the spirit of the deceased to remain in the company of the living as long as possible, so that he may "see" the mourners and watch the performance of the cattle-drive and the sham fight while he is not yet buried. Infants and small children, on the other hand, are usually buried a few hours after they have died, a custom which is in accordance with the prevailing notion that the spirits of children are "powerless" and that it is therefore not necessary to take much trouble over them. 
European Journal of Philosophy, Culture and Religious Studies

ISSN 2520-4696(Online)

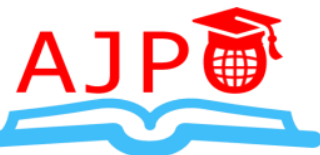

Vol.1, Issue 1 No.1, pp1-15, 2017

An average funeral expense list covers the meeting venue, transfer of body (mostly from hospital mortuary to funeral home), daily storage charges, post-mortem examination, embalming, body make-up, advertisement and epitaph stone. Other expenses go to food before and on the burial day, attire for close kin and even video coverage. The list below shows, for example, the expenses of a businessman's burial at Mumbita Village in Emuhaya District.

(Permission was granted by the Ombima's family to use their budget for their deceased as an example in this study).

\section{Table 1: Funeral Budget}

\begin{tabular}{|c|c|c|c|}
\hline ITEMS & COST & ITEMS & COST \\
\hline Meeting venue & $\begin{array}{l}\text { @ } 1,500 \text { per day } \\
15,000\end{array}$ & $\begin{array}{l}\text { Transport of } \\
\text { mourners from } \\
\text { Nairobi to Luanda }\end{array}$ & 50,000 \\
\hline $\begin{array}{l}\text { Transfer of body to } \\
\text { funeral home }\end{array}$ & $3,000 /=$ & Lowering gear & 10,000 \\
\hline $\begin{array}{l}\text { Daily } \quad \text { storage } \\
\text { charges }\end{array}$ & $\begin{array}{l}\text { @ } 1000 \text { per day } \\
10,000\end{array}$ & Epitaph stone & 5,000 \\
\hline Autopsy & 10,000 & Food & 50,000 \\
\hline Embalming & 15,000 & Attire for close kin & 20,000 \\
\hline Body maker & 5,000 & $\begin{array}{l}\text { Public } \quad \text { address } \\
\text { system }\end{array}$ & 5,000 \\
\hline $\begin{array}{l}\text { Advertising four } \\
\text { days }\end{array}$ & 32,000 & Video & 8,000 \\
\hline Coffin & 50,000 & Still photographs & 5,000 \\
\hline $\begin{array}{l}\text { Hearse from Nairobi } \\
\text { to Kisumu then to } \\
\text { Luanda }\end{array}$ & 40,000 & Miscellaneous & 5,000 \\
\hline $\begin{array}{l}\text { Air transport from } \\
\text { Wilson airport to } \\
\text { Kisumu }\end{array}$ & 19,000 & & \\
\hline & & TOTAL & 357,000 \\
\hline
\end{tabular}

Source: Field Data

The above budget culminates in the grave shown below, thus indicating how much money was used during funeral and burial ceremony: 
European Journal of Philosophy, Culture and Religious Studies

ISSN 2520-4696(Online)

Vol.1, Issue 1 No.1, pp1-15, 2017

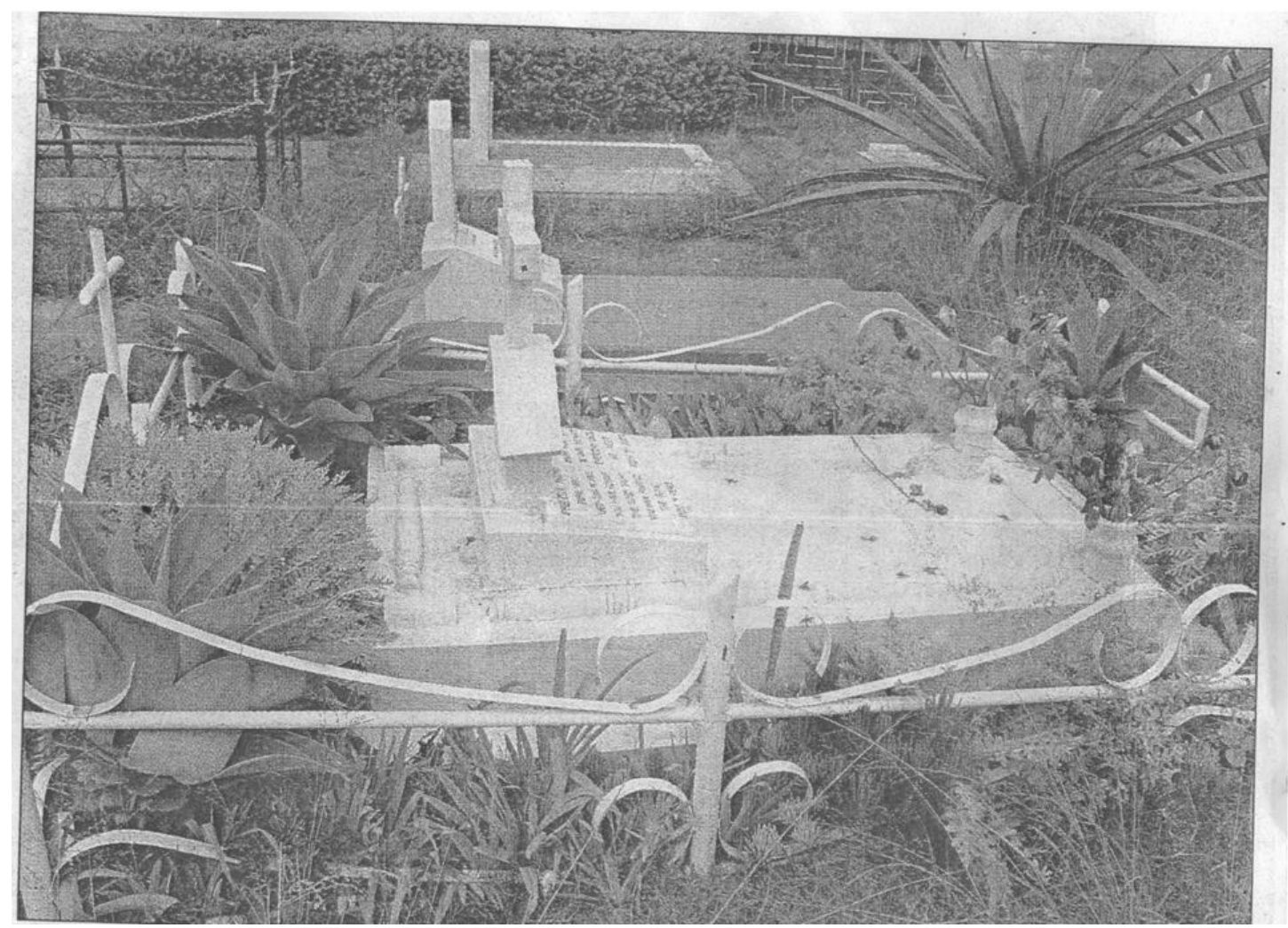

Figure 1: Grave

Source: Field Data

The send-off depends on the status of a person. The higher the social status of the person, the more pompous the send-off. The living believes that the dead are still watching over them in a spiritual form. Death is transformation into another form, thus the dead continue to interact with the living and so the dead are always handled with respect lest they return to haunt the living. Ochola (OI, 11/11/2008) cites naming of children after the dead as proof of this belief. Naming children preserve the memory of the dead after them, a concept called nominal reincarnation (Ibid.). This means the character of the dead is expected to be manifested in the newborn. The send-off is a product of socialization. For example, People who acquire leadership roles in society are deemed more important, thus when they die, are accorded posh funerals compared to children or uncelebrated people. This explains the great feasts and huge funeral expenses when the aged and leaders die.

Among our people, visitors are accorded warm welcome and food. During funerals, host tries to create a lasting impression, lest they annoy the spirits. It is inherent in African culture where people tend to love each other, they show that is extended when one dies (Imbayi: OI, 08/08/2008).

That belief is strong among the FBO members. It is not the money thinking but cultural thinking. People are not looking at the cost involved but the proper handling of the dead (Ibid.). The more prominent and important the person, the more people are willing to contribute to accord him/her a decent send-off. 
The FBO holds that the last very important celebration a person can receive is the last rites performed at the funeral service. The importance of this ceremony is driving evil spirits out and praying for God's blessing for the dead person. Songs of joy accompanied by dancing, jumping and limping predominates the mourning atmosphere. During the burial worship cerebration, the preacher uses this forum to ask members to contribute generously towards the bereaved family so as to meet other financial costs that they might have incurred.

The most important ceremony held for the person who had died where again a lot of money is used is the memorial meeting, forty days after burial. Just as Jesus ascended to heaven forty days after his resurrection; according to Acts (1:1-11), the dead person is thought to go to heaven on that day if he or she had been a faithful Christian. A meeting attended by many people, both members and non-members is held and there is much singing and joy to celebrate the dead person's final residence in heaven. People's actions are remembered and when they die, everything they had done is looked into. The judgment as such is not described much by the members of the FBO, since they believe that God can see one and all, and that He knows all the things that one does (Okoko: OI, 11/12/2008). Therefore, no one can hide anything from Jesus Christ who will be the judge.

In this context, God and Jesus appear to be looked upon as judges. What is seen as important is the belief in the judgment and as such, not the way in which it will be carried out. It may be significant that Jesus can be described as the judge because there is no talk of mercy in connection with the judgment. Once you have died, nothing can be done to save you; once you have entered the grave, there is no way to be saved. Your actions while alive are the only factor that decides whether you will be accepted in heaven or sent to the sea of fire.

The notion of life after death is not something new that was introduced into the people's ways of thinking by christian missionaries. Among the FBO members, the continuation of life beyond death was taken for granted. When people died, their spirits were thought to leave their bodies for the spirit land (Otiato: OI, 18/08/20008). As has already been seen, these spirits were believed to retain a certain relationship with the living. They could visit living relatives in their dreams, and had the power to influence their health and general well-being in a positive or negative direction (Wagner; 1949: 159). But, as Mbiti pointed out, this way of looking at life after death in the traditional African religions gave nothing for which to hope (Mbiti; 1969:165). There was no hope of resurrection or of growing towards God. Rather, the existence of the spirits was thought to be timeless. They were believed to gradually lose more and more of their human nature, until eventually their individual characters were completely forgotten and they became incorporated into the collective body of impersonal spirits (Ibid.).

What was new in the missionaries' teaching, therefore, was the emphasis on heaven as a better place than the present world. They did not preach simply the immortality of the soul, but rather its resurrection to the highest salvation in heaven. A new hope was introduced and the reinterpretation of an expectation of a life after death had a great impact on the people who came to form the CoG-K. As long as the traditional cultural pattern was untouched and the life of the clan was still looked upon as an integrated whole, the old way of looking at life after death was sufficient.

The continuation of the existence of the spirit in a spirit world was not thought to be radically different from these traditional beliefs (Muhia: OI, 28/12/2008). But when the patterns of life 
were broken down by the introduction of colonialism with its many and radical changes, this traditional concept of life after death became unsatisfactory. Many of the old institutions in which the spirits of the ancestors played an important role were broken down, and it was therefore difficult to uphold the belief in the spirit world in its old form.

At the same time, the missionaries came with biblical teachings about future dimension of time in which this old world would come to an end and a new, perfect world would come into existence (Anjere: OI, 23/12/2007). In the colonial situations, with all the insecurity it brought to the Africans, this message was received eagerly because it created a hope that some day the oppression, moral evils and instability they were experiencing in this world would stop and a new harmonious life would begin. They still wait for this goal to come. This explains why the FBO questions the relevance of the missionary teachings in the face of the continued occurrence of death, suffering and poverty among their Christian relatives.

The question that emanates from the foregoing discussion is whether culture promotes or retards the spiritual and economic development among the FBO members in Emuhaya District. This has partly been answered by the respondents' arguments by several respondents. Cultural observation by the people according to some CoG-K leaders, to some extent retard development. The major example that emerged was death and funeral practices. Some CoG-K programs were also reported to retard economic growth; this includes church programs like ordination, baptism and marriage. These were noted to exploit the already poor people due to the expenses that accompanied such celebrations.

\subsection{Social-Economic Challenges Facing the FBO's in Poverty Alleviation in Emuhaya District}

The study has found out that the FBOs members participated in various religious, social and economic activities that posed a challenge to its programs aimed at alleviating poverty in Emuhaya District. There is a tendency to use huge amounts of resources for celebrations and ceremonial functions, weddings, ordination to priesthood, and funerals. On funerals, for example, the practice of slaughtering the livestock for celebrations has fuelled poverty within families and local communities. From this observation, the study shows that the FBO celebrations are often accompanied by a wasteful consumption of scarce resources, which prevents adherents from the fruits of considerable investments that have been made over years.

These activities were mainly influenced by the adherent's worldview in Emuhaya District. Consequently, poverty in Emuhaya District may persist, with people's participation in the social cultural and spiritual activities that impede the development. The study concludes that material concerns of the church were as relevant as the spiritual needs of the people in Emuhaya District. Thus, the church is expected to help her members by liberating and reconstructing their lives by alleviating poverty amongst them.

\subsection{CONCLUSION AND RECOMMENDATIONS}

\subsection{Conclusions}

Based on Objective one, the study concludes that the CoG-K's teachings are largely pertinent in the development of FBO members and their participation in activities that are designed along people's development needs. They have subsequently been essential in terms of local 
people's accessing resources for improving their livelihood. However, the paucity of resources has aggravated a dependency syndrome in the FBO programs, which has left most activities of the programs not self sustaining.

Based on objective two, the study proved that the CoG-K has a role to play through her programs like Sisi kwa Sisi, Child Development Centres, Health care Units and education, thus these institutions make a significant contribution to sustainable development in Emuhaya District and are useful instruments for spearheading alleviation of poverty in the said district. The FBO's development is founded upon a spirituality of mutual sustenance and transformation through its concern for the adherents' struggle with poverty. This study found out that faith activities and the related projects implicitly advance the poverty alleviation cause, thus all development revolves around spirituality. From this perspective the FBO's has the responsibility to engage in all aspects of development within spirituality as the foundation of such engagement.

Based on objective three, the study concludes that as much as the FBO has made concerted attempts towards development in Emuhaya District by influencing the peoples thinking on legitimacy of wealth and education, and on the moral value of saving and investing. However some of its programs and ceremonial functions like ordination, baptism, marriage and weddings tend to retard these efforts of alleviating poverty. Although such programs and celebrations serve the poor at the grassroots level, they delay change in behavioural and institutional transformation capable of sustaining economic growth.

\subsection{Recommendations}

This research recommends that if Emuhaya District is to develop, it has to place the FBO teachings and theology of option for the poor at the top of the agenda and to consider it as is so often the case, as adjunct to the real core of the work that is, development. The study proposes that for the FBO to improve her input in social concerns of the people, it should reshape its theology of development so that it can fully address the plight of the poor. This study also recommends that studies be done to establish the impact of specific doctrines of the FBO that have an effect on the economic growth.

The study submits to the fact that power lies in the FBO's projects which, subsequently play a positive role in alleviating poverty in Emuhaya District. As a result, these study findings suggest that development will in future need to be considered in term of religious teachings. The study recommends that development experts, theologians, policy makers and practitioners should cultivate long-term relationship with the church in general and the CoG$\mathrm{K}$ in particular so as implement policy for development consequently alleviating poverty.

There is a need to change cultural practises that tend to retard development among the adherents of the FBOs's in Emuhaya District. The study posits that cultural practices surrounding marriage and death that are repugnant and detrimental to change should be discarded if development is to take place.

\section{REFERENCES}

Albertini, R. V. (1980), Colonialism and Underdevelopment: Critical Remarks on the Theory of Dependency. Leiden: Leiden University Press. 
European Journal of Philosophy, Culture and Religious Studies

ISSN 2520-4696(Online)

Vol.1, Issue 1 No.1, pp1-15, 2017

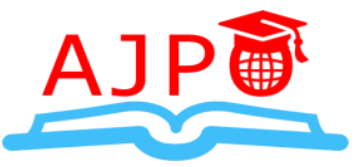

Alela, M. (2007), Good News to the Poor: A Model for Holistic Christian Ministry in Bunyore, Kenya. Unpublished Ph.D Thesis: Asbury Theological Seminary.

Assman, H. R. (1976). Theology for A Nomad Church. New York: Orbis Press.

Ayanga, H. O. (1999). The Secularization Process and Its Impact on Christianity in Kenya: Eldoret as a Case Study. Unpublished Ph.D Thesis: Moi University.

Babbie, E. (1998), Social Research Methods. Belmont: Wadsworth Publishing.

Barret, D. B. (1975), African Initiatives in Religion. Nairobi: East African Publishing House.

Belshaw, D. (2001), Faith in Development: Partnership Between the World Bank and Churches of Africa. Oxford: Regnum Books International.

Bob, G. (1995), Beyond Poverty and Affluence. New York: Oxford University Press.

Bradshaw, B. (1997), Christian Witness and Transformational Development. Monrovia: MARC.

Bryne, T. (1970), The Church and Development Dilemma. Eldoret: Gaba Publishers.

Burkey, S. (1993), People First: A Guide to Self-Reliant, Participatory Rural Development. New York: Zed Books Ltd.

Chambers, R. (1996), Rural Development: Putting the Last First. Essex: England Longman.

Craige, B. L. (1999), Neither Poverty nor Richness. Illinois: Essex Publishers.

Daily Nation (2004). Nairobi Women. Nairobi: Nation Media Publishers.

Dunne, G. (1964). Poverty in Plenty. New York: Orbis Books. Educational Publishers.

Galgalo, J. D. (2005). African Christian and the Contemporary Market Place: Materialism and the Theology of Moderation. Butere: Chadwick.

Gonzalez, J. (1987). A History of the Christian Thought: from the Protestant Reformation to the Twentieth Centaury. Nashville: Abingdon Press.

Government of Kenya. (1998). The First Report on Poverty in Kenya: Poverty and Social Indicators. Nairobi: Government Printers.

Government of Kenya. (2002). Development Indicators from the 1999 Kenya Population and Housing Census. Nairobi: Government Printers.

Gustavo, G. (1968), Liberation Theology. Grand Rapid: Eerdman Publications. Human Development in Africa. Nairobi: Pauline Publishers. 
European Journal of Philosophy, Culture and Religious Studies

ISSN 2520-4696(Online)

Vol.1, Issue 1 No.1, pp1-15, 2017

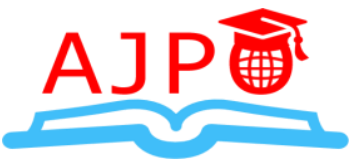

Kageni, B. (2008), No Expense is Spared When Death Calls. Nairobi: Nation Media Press.

Kemp, C. F. (1975), Pastoral Care with the Poor. Indiana: Abingdon Press.

Kimambo, L. (1999). East African Expression of Christianity. Nairobi: East African Educational Publishers.

Krueger, J. (1998). Focus Groups: A Practical Guide for Applied Research. Newsbury: Sage

Marja-Liisa, S. (1985). Women in Development: A Creative Role Denied? New York: Martin Press.

Mazrui, A. A. (1990). Cultural Force in World Politics. London: James Curry Publishers.

Mbiti, J. S. (1996). African Religion and Philosophy. Nairobi: Heinemann Publishers.

MDG Center. (2009). Taking Action to End Extreme Poverty. Nairobi: Acton Publishers.

Meeks, D. (1989). God the Economist: the Doctrine of God and Political Economy. Minneapolis: House Press.

Myers, C. (1999). Walking with the Poor: Principles and Practice of Transformational Development. Maryknoll: Orbis Books.

Nandy, A. (1998). Tradition, Tyranny and Utopia. Bombay: Oxford University Press.

Nyongo, A. (1990), Regional Integration in Africa. Nairobi: Academic Science Publishers.

O’Brien, J. (1992), Theology and the Option for the Poor. Michigan: A Michael Glazier

Publishers.

Ochola, J. N. (2001), A Comparison of Values and Aspirations of the Members of the Trustees and the Faculty of Theological Colleges in Kenya. Unpublished Ph.D Thesis: Graduate School of the University of South Mississippi.

Office of the Member of Parliament. (2010), Emuhaya Development Plan. Nairobi: Citizen Press.

Ogot, B. A. (1999), Building on the Indigenous; Selected Essays 1981 - 1998. Nairobi: Regal press.

Okullu, H. (1987), Church and Politics in East Africa. Nairobi: Uzima Press.

Otieno, J. O. (2007), Economic Development and the Church. Nairobi: Nation Media Publishers. 
European Journal of Philosophy, Culture and Religious Studies

ISSN 2520-4696(Online)

Vol.1, Issue 1 No.1, pp1-15, 2017

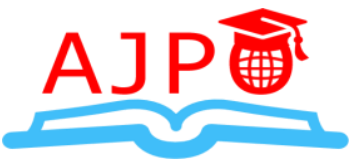

www.ajpojournals.org

Paradox of Poverty in Africa". In Kanyandago P. (Ed). The Cries of the Poor in Africa: Questions and Responses for African Christianity. Uganda: Kisubi Publishers.

Plant, R. (2001), Politics, Theology and History. Cambridge: Cambridge University Press.

Pope Pious. (1967), Liberation Theology. Grand Rapids: Eerdman Publications.

Prandervand, P. (1990), Listening to Africa; Developing Africa from the Grass Roots. New York: Praeger Publisher.

Rasmussen, T. (1996), Christian Responsibility in Economic Life. Philadelphia: Westminster Press.

Saitoti, G. (2002), Economic Development. Nairobi: Government Printers.

Singleton, M. Q. (1988), Qualitative Evaluation Methods. Newbury Park: Sage Publications.

Speckman, M. T. (2001), Relief, Foreign Aid and Making of A Beggar in the Bible and Human Development in Africa. Nairobi: Pauline Publishers.

Staffold, G. S. (2005), Strategic Planning. Nairobi: Heinemann Publishers.

Sugden, S. (1987), The Church in Response to Human Needs. Oregon: Wipf and Stock

Tylor, J. V. (1975), Enough is Enough. London: SMC Publishers.

UNDP. (1996), Progress Against poverty: A Report on Activities since Copenhagen UNDP Progress Report. New York: UNDP Publications.

UNDP. (2003), Human Development Report: Gender Work. New York: UNDP Publications.

Vinay, S. (1999), Mission as Transformation. Oxford: Regnun Publishers.

Wako, D. M. (1985). The Western Abaluyia and Their Proverbs. Nairobi: Heinemann Publications.

Wanyama, F. (2003), Local Organizations for Sustainable Development; the Political Environment of the Community Based Organizations in Western Kenya. Unpublished Thesis: Maseno University.

Wengraf, T. (2001), Qualitative Research Review: Biographical Narrative and Structured Methods. London: Sage Publications. 